Article

\title{
Alexis Wright's The Swan Book: Indigenous-Australian Swansong or Songline?
}

\author{
Cornelis M. B. Renes
}

check for

updates

Citation: Renes, Cornelis M. B. 2021.

Alexis Wright's The Swan Book:

Indigenous-Australian Swansong or

Songline? Humanities 10: 89.

https://doi.org/10.3390/h10030089

Received: 14 November 2020

Accepted: 29 June 2021

Published: 15 July 2021

Publisher's Note: MDPI stays neutral with regard to jurisdictional claims in published maps and institutional affiliations.

Copyright: (C) 2021 by the author. Licensee MDPI, Basel, Switzerland. This article is an open access article distributed under the terms and conditions of the Creative Commons Attribution (CC BY) license (https:/ / creativecommons.org/licenses/by/ $4.0 /)$.
Department of Modern Languages and Literatures and English Studies, University of Barcelona, 08007 Barcelona, Spain; mrenes@ub.edu

\begin{abstract}
The Swan Book (pub. 2013) by the Indigenous-Australian author Alexis Wright is an ecodystopian epic about the Indigenous people's tough struggle to regain the environmental balance of the Australian continent and recover their former habitat. The book envisions a dire future in which all Australian flora and fauna-humans included-are under threat, suffering, displaced, and dying out as the result of Western colonization and its exploitative treatment of natural resources. The Swan Book goes beyond the geographical and epistemological scope of Wright's previous two novels, Plains of Promise (pub. 1997) and Carpentaria (pub. 2006) to imagine what the Australian continent at large will look like under the ongoing pressure of the Western, exploitative production mode in a foreseeable future. The occupation of Aboriginal land in Australia's Northern Territory since 2007 has allowed the federal government to intervene dramatically in what they term the dysfunctional remote Aboriginal communities; these are afflicted by transgenerational trauma, endemic domestic violence, alcoholism, and child sexual and substance abuse-in themselves the results of the marginal status of Indigeneity in Australian society-and continued control over valuable resources. This essay will discuss how Wright's dystopian novel exemplifies an Indigenous turn to speculative fiction as a more successful way to address the trials and tribulations of Indigenous Australia and project a better future-an enabling songline rather than a disabling swansong.
\end{abstract}

Keywords: Indigenous Australia; The Swan Book; Indigenous sovereignty; slow violence; ecodystopia; environmentalism; climate change

\section{Introduction}

The Swan Book (pub. 2013) by the Indigenous-Australian author Alexis Wright is an eco-dystopia about the Indigenous people's struggle to regain the environmental balance of the Australian continent and recover their former country and habitat, the object of white land theft as of first contact. Wright's dystopian novel does so by envisioning a dire future in which all Australian flora and fauna-humans included-are under threat, suffering, displaced, and dying out as the result of Western colonization and its exploitative treatment of natural resources. The Swan Book goes beyond the geographical and epistemological scope of Wright's previous two novels, Plains of Promise (1997) and Carpentaria (2006), and imagines what the Australian continent at large will look like under the ongoing pressure of the Western, exploitative production mode in a foreseeable future. Given the ongoing nature of the Northern Territory Emergency Response, initiated in 2007 and continued ever since with bipartisan support, there are good reasons for Wright to choose a dystopian format for her last novel, as the Indigenous Australian context responds well to the existence of what Rob Nixon coined destructive frameworks of "slow violence" that affect disenfranchised minorities globally (Nixon 2011, p. 3). This essay seeks to respond to the question whether Wright's The Swan Book creates a swansong of Australian Indigeneity's imminent demise or a songline into an invigorating future for the First Nations. 


\section{The Equivocal Insidiousness of "Slow Violence"}

In a study that links violence, activism, ecology and the literary, Rob Nixon defines "slow violence" as "a violence that occurs gradually and out of sight, a violence of delayed destruction that is dispersed across time and space, an attritional violence that is typically not viewed as violence at all" (Nixon 2011, p. 2). Whereas violence is normally associated with spectacle and fast impact, slow violence is equivocal and only comes to light over longer periods of time, as with the impact of toxins, illness, drug abuse, lack of employment, politics of separation, etc. Not surprisingly, slow violence is common fare among disenfranchised minority groups who lack access to political, economic and social resources. Nixon defines such minority groups as "a compendious category subject to almost infinite local variation as well as to fracture along fault lines of ethnicity, gender, race, class, region, religion, and generation" (Nixon 2011, p. 4). Given the often appalling living conditions in their remote communities, the "Fourth World" of Australia's Indigenous peoples should be included as well ${ }^{1}$.

Slow violence informs the academic and political debate on Aboriginal dispossession, displacement, dispersal and assimilation, in which colonization (and now neo-colonization) is described as either benign or destructive. The benign settlement paradigm that has reigned Australian race relations for so long disguises the harm inflicted through the Stolen Generations, Aboriginal death in custody, the amended Native Title legislation, underfunding of basic Aboriginal services etc.), and paints these as unharmful. Significantly, the benign settlement paradigm promoting Indigenous assimilation into the mainstream has been resistant to critique because of the way genocide has traditionally been associated with the industrial efficiency, speed and scope deployed by the Nazis in the Holocaust. Genocide has been a controversial term in its Australian application, as varying state policies of different periods may not fit the official, Holocaust-based UN definition of the intentional destruction of a racial, ethnic, national or religious group, so "scholars have wrangled with one another over the meaning of genocide, or suggested alternative definitions" (Moses 2005, p. 23), opening discursive spaces where neo/colonial violence may be white-washed.

Yet, the Indigenous law expert Larissa Berendt's finds that "the political posturing and semantic debates do nothing to dispel the feeling Indigenous people have that [genocide] is the word that adequately describes our experience as colonized people" (Behrendt 2001, p.132). Not only does the industrial mass murder of millions of Jews in only half a decade by the Nazis define genocidal violence as "immediate in time, explosive and spectacular in space" (Nixon 2011, p. 2), but this mass murder also helps obscure the impact of slow violence on colonized minority groups, such as in the use of euphemistic rhetoric. For example, "smoothing the dying pillow" 2 referred to white settler society speeding up Indigenous Australian extinction so as to make room for an imperial civilization that considered itself fitter for survival than the Aboriginal First Nations, presenting this process as fair and natural. Thus, we may accept Nixon's argument that "[w]e need to account for how the temporal dispersion of slow violence affects the way we perceive and respond to a variety of social afflictions-from domestic abuse to posttraumatic stress and, in particular, environmental calamities" (Nixon 2011, p. 3). Evidently, the Indigenous eco-dystopia is a writerly attempt to do so.

The insidiousness of slow violence could precisely be the reason why Alexis Wright projects her critique of Western land and resource management from a dystopian, future point in time, the year 2100, which allows her to imagine the evidence of slow violence's accrued impact on the environment and Indigenous society. It allows her to predict serious environmental disaster for the continent at large if Western "progress" and its exploitation of finite resources is to prevail. Western civilization has had a degrading effect on the Indigenous habitat of the Australian continent ever since first contact at the end of the 18th c, leading to Aboriginal dispersal, dislocation, disempowerment and destruction, though these terms remain contentious. The hidden, slow violence with which the genocidal process has taken place informs the tension between the paradigms of "benign settlement" 
and "violent invasion", the focus of heated academic debate. In the new millennium, the controversial right-wing historian Keith Windschuttle sparked off the so-called 'History Wars' when launching a frontal attack on the New Australian History with his volume The Fabrication of Aboriginal History (2002):

"The British colonization of this continent was the least violent of all Europe's encounters with the New world. It did not meet any organized resistance. Conflict was sporadic rather than systematic. Some mass killings were committed by both sides but they were rare and isolated events where the numbers of dead were in the tens rather than the hundreds. The notion of sustained 'frontier warfare' is fictional. A great many Aborigines willingly accommodated themselves to the transformation" (Windschuttle 2002, p. 3).

Robert Manne's collection Whitewash (2003) and Bain Attwood's in-depth analysis of Windschuttle's work in Telling the Truth about Aboriginal History (2005), among others, respond to these claims. Robert Manne points out that until recently "both scholars and citizens had [ ... ] failed to integrate the story of [Aboriginal] dispossession and its aftermath into their understanding of the course of Australian history" (Manne 2003, p. 1), and flags Windschuttle as a symptomatic case. Bain Attwood agrees with Manne:

In Australia, the last three or more decades have been punctuated by major debates over land rights, native title, a treaty, the removal of Aboriginal children (the stolen generations) and reconciliation. There has been a struggle over who controls this past, who can influence the interpretation of this past, and who can determine the historical truth about the nature of colonialism" (Attwood 2005, pp. 1-2).

The intensity with which these "wars" have been fought reflected the immense emotional and material stakes involved in the assignment of accountability for land theft and genocidal imposition by European Australians. Ken Gelder and Jane Jacobs locate Indigenous land claims "as crucial in the recasting of Australia's sense of itself" (Gelder and Jacobs 1998, p. 3). They see the psycho-spatial parameters of Australianness as disturbingly unsettled by the 1990s legislation as it offers the Indigenes a possibility to retrieve lands they lost by the application of the legal concept of terra nullius ${ }^{3}$ during colonization (Gelder and Jacobs 1998, p. 44). Henry Reynolds comments that Terra Nullius

[... ] means both a country without a sovereign recognised by European authorities and a territory where nobody owns any land at all, where no tenure of any sort exists [...] European powers adopted the view that countries without political organisation, recognisable systems of authority or legal codes could legitimately be annexed. It was a case of supplying sovereignty where none existed (Reynolds 2003, pp. 14-15).

The slow, hidden character of the European imposition on Indigenous Australia has allowed settler Australians to deny the genocidal results of attempts to "absorb" and "assimilate" the Indigenous nations into the Western pace of life, and present this as beneficial. In terms of their ongoing disenfranchisement, it is evident that the Aborigines and Torres Strait Islanders belong to "those people lacking resources who are the principal casualties of slow violence. Their unseen poverty is compounded by the invisibility of the slow violence that permeates so many of their lives" (Nixon 2011, pp. 2-4). But "if the neoliberal era has intensified assaults on resources, it has also intensified resistance" (Nixon 2011, p. 4), so that Nixon foregrounds the engagement of writer-activists that resist and voice "the environmentalism of the poor" (Nixon 2011, p. 4), listing the following examples in a global context: Wangari Maathai (Kenya), Arundhati Roy (India), Indra Sinha (India), Ken Saro-Wiwa (Nigeria), Abdulrahman Munif (Saudi Arabia), Njabulo Ndebele (South Africa), Nadine Gordimer (South Africa), Jamaica Kincaid (Antigua), Rachel Carson (US), and June Jordan (US) (Nixon 2011, p. 5). We may add Alexis Wright, who started out in Indigenous activism and has written a fictional and non-fictional oeuvre that gives testimony to her political activism and holistic environmentalist agenda. 


\section{Indigenous-Australian Fact and Fiction}

Indigenous-Australian literature is a fairly new phenomenon that has quickly developed into a fertile area of creation and innovation inspired by a firm commitment to country and culture. In the wake of the civil rights movements of the 1960s, which sought to give voice to oppressed minorities worldwide, the 1970s and 1980s saw a great surge in often female Indigenous life writing. Authors such as Sally Morgan, Doris Pilkington, Marnie Kennedy, Jack Davies and Fiona Doyle wrote autobiographies that enabled them to address the traumatic hardships Aborigines had suffered under colonization:

... life writing has proved a particularly attractive genre for Indigenous Australians wishing to re-vision and re-write historical accounts of invasion, settlement and cross-cultural relationships from individual, family and communitybased Indigenous Australian memories, perspectives and experiences. In so doing, life writing has constituted a dynamic form of historical intervention that both revises colonial historical narratives and also challenges, in its articulations as 'history from below', the generic paradigms in which such histories may be inscribed and represented, and by whom (Grossman 2006, p. 10).

Yet, the autobiographical claim on factual truth allowed mainstream scrutiny of the historical accuracy of Indigenous accounts of destruction and survival, and to shed doubt on and contest the veracity of the events depicted in life writing. Thus, newer generations of Indigenous writers have moved into speculative fiction as a more effective way to critique the white version of Australian History and Australianness while warding off debilitating debates that question the truthfulness of their narratives. Wright uses fiction to represent a reality that is "truer than the truth", that is, in fiction she finds the space to express her views on the state of Aboriginality that could be more easily questioned in factual, documentary writing (Wright 2002, p. 13; Kunhikrishnan 2003a, 2003b). It allows her to lay bare the genocidal impact of the mainstream on Aboriginal culture, euphemistically conceptualized as "benign settlement", aided by the legal fantasy of Terra Nullius and furthered by a politics of "smoothing the dying pillow" carried out by a purportedly superior race, the white Europeans.

The genres explored to build a corpus less vulnerable to mainstream scrutiny of the "facts" are various, and authors may recur to dystopian fiction to give shape to a future where Aboriginality defies benign settlement and survives against all odds. A dystopia is "[a]n imagined state or society in which there is great suffering or injustice, typically one that is totalitarian or post-apocalyptic" (OED 2021). The Indigenous-Australian dystopia is built upon the perception that post-apocalyptic Australia started at first contact, and it typically considers the extant Indigenous population survivors of the process of colonization and its neocolonial aftermath. It finds strength in looking back to a past that will not be forgotten, highlighting Indigenous resilience as well as painting a dire future for the continent at large if contemporary exploitation and abuse of finite natural resources is to continue on Western terms, which makes these narratives ecologically concerned. There is a levelling, environmentalist, holistic vein in the Aboriginal Law and Dreamtime (Bird Rose 2000, pp. 40-49) that enable eco-dystopias as songlines into the future rather than turning them into swansongs.

\section{Wright as an Indigenous Environmental Writer-Activist}

Alexis Wright is a member of the Waanyi people in the Gulf of Carpentaria, a mob that has been expelled from its traditional lands and dispersed in the process of colonization. As mentioned above, Wright fits into Rob Nixon's model of the "environmental writer activist" developed in his study Slow Violence, defining them as "combative writers who have deployed their imaginative agility and worldly ardor to help amplify the mediamarginalized causes of the environmentally dispossessed" (Nixon 2011, p. 5). Wright uses non-fiction and speculative fiction to deliver an epistemic and holistic critique of the slow, but deeply traumatic and still too unrecognized impact of white Australia on Indigenous country over 250 years of colonization. She has worked across different literary genres 
and modes with an agenda of Indigenous emancipation and sovereignty. Her non-fiction The Grog War (pub. 1997), Take Power (pub. 1998), and Tracker (pub. 2017) attests to these objectives too, analyzing and commenting on Indigenous alcoholism, local history, and grassroots politics, respectively. Thus, she gives evidence of what Rob Nixon calls "the versatile possibilities of politically engaged nonfiction" in activism (Nixon 2011, p. 25). Indeed, It was only her activist years, during which she worked extensively in government departments and Indigenous agencies across four states and the Northern Territory, that prompted her to pursue her literary calling through media studies and creative writing courses (Wright 2002, p. 11). The non-fiction resulting from her activist years forms the bridge to her fictional oeuvre, which explores Indigenous sovereignty in the broadest sense of the word.

After the magic-realist novel Plains of Promise and the epic Carpentaria, her dystopian The Swan Book imagines what the Australian continent will be like in the year 2100 if capitalist exploitation of the land resources and concomitant political manipulation are to continue unaltered. Set in traditional Waanyi country The Swan Book recovers, maintains, and reinvents the cultural memory and spiritual connection of Wright's "distant illusionary homelands" (Wright 2013, p. 4). Critical with the material and discursive reality in which it is embedded, Wright's eco-dystopia can be seen to operate on the disturbing edges of cultural tradition and performance, beckoning toward Indigenous incommensurability with mainstream understandings of reality while actively engaging with, and soliciting, the mainstream's assimilationist attitudes. This incommensurability is intended to create a discursive space/place where Indigeneity can come to terms with itself and achieve a sovereignty of mind and body within and beyond the larger framework of the Australian nation-state.

The Swan Book forces non-Indigenous readers to acknowledge they are visiting unknown and uncharted narrative territory and are led into what Wright has tentatively coined the genre of Aboriginal Reality, in opposition to magic realist and fantastic readings of her work (Renes 2002, pp. 76-102) ${ }^{4}$; rather, readers are coaxed to relinquish established, canonical reading practices, genre and content as the only way to make sense of the textual landscape, the Indigenous Other, and themselves. In The Postcolonial Eye (2012), Alison Ravenscroft makes a strong case for intercultural incommensurability as well as respect. By refusing to be assimilated into a hierarchical Enlightenment epistemology of the western world, The Swan Book is a work of imaginative fiction that acquires dystopian features. At heart, what Ravenscroft calls white "postcolonial blindness" (Ravenscroft 2012, p. 1) — the impossibility to see beyond Western epistemology and to accept cultural difference-is structurally projected from all fronts of the public realm of the Australian nation-state onto the disempowered and disenfranchised Indigenous communities. At present, this is most visible in the remote Northern Territory (NT), where a bipartisan federal intervention has maintained a structural policy of ethnic assimilation and control along neoliberal lines. Not constituted and empowered as a state within the Australian nation, the NT boasts the largest Aboriginal population of all territories in relative terms, and is therefore vulnerable to federal control and imposition.

Wright's dystopian epic can be considered a literary equivalent of a songline, the musical mnemonic device by which Aborigines narrate or "sing" country into being and place, and so fix and transmit orally defining features of their environment and its inhabitants from one generation to another. Songlines form part and parcel of the so-called Indigenous Dreaming or Dreamtime, whose secret/sacred knowledge enables Aboriginal societies to keep up their Law and Culture and chart as well as claim the territory they have been living in for thousands of generations. Dreamtime knowledge is in the custody of authorized caretakers and it inspires the Aboriginal Law, which guarantees their survival within their environment on a holistic, levelling, non-anthropocentric basis (Bird Rose 2000, pp. 40-49) $)^{5}$. Whereas Carpentaria adapts the iconic Western epic form to create an Indigenous sense of community emanating from country and its embodied cultural practices despite assimilation, The Swan Book does the opposite by pointing towards a 
dire future conditioned by the current clash of mainstream and Aboriginal Australia, and so offers a dystopian reflection on the likely future consequences for the Indigenous community. In the latter sense, it was an ironic, significant wink of fate that The Swan Book's prequel, Carpentaria, received the highest Australian literary honors and recognition, the Miles Franklin Literary Award, on the very day that the federal onslaught on remote Aboriginal communities known as the NT Invasion began:

On 21 June, the day "Carpentaria" was announced as the winner of the Miles Franklin, the conservative Prime Minister John Howard announced a ban on alcohol and pornography in the Northern Territory as part of an effort to combat child abuse, which a government report found to be widespread in Aboriginal communities. Soon thereafter, small groups of Australian soldiers were dispatched by the government to Aboriginal settlements to enforce the no-drinking edict (Perlez 2007).

Inevitably, as can be seen in this episode, Alexis Wright's oeuvre is intimately bound up with the political.

\section{The Swan Book as a Reply to the Northern Territory Emergency Response}

As with Plains of Promise's protagonist Ivy Koopundi, Oblivia Ethyl(ene) Oblivion's life is wrapped in silence, madness, and fear in a destructive downward spiral of race and gender oppression. She is, like Ivy, a victim of rape, not by a white missionary this time but-worse-by ethylene-drugged, out-of-control youngsters from her own mob, which upsets her future designed as the wife elect to the intended first Indigenous Prime Minister-cum-'savior' of Australia, Warren Finch. Like Plains of Promise's Ivy, Oblivia is tainted by sexual abuse, and though not responsible for committing what is considered an infringement upon taboo or a sin, she is no longer pure-that is, eligible for 'healthy' and 'honorable' marriage-and so condemned to staying alone, in yet another painful comment on the sexual politics of guilt and shame that have pervaded Indigenous communities so destructively (Grossman 1998, pp. 84-85). The shift from missionary authority to black kin in the victimizer role is no doubt conceived in the context prior to the contentious 2007 government report Little Children are Sacred, which analizes child sexual abuse in dysfunctional remote Indigenous communities:

The classic indicia of children likely to suffer neglect, abuse and/or sexual abuse are, unfortunately, particularly apparent in Aboriginal communities. Family dysfunctionality, as a catch-all phrase, reflects and encompasses problems of alcohol and drug abuse, poverty, housing shortages, unemployment and the like. All of these issues exist in many Aboriginal communities (Wild et al. 2007, p. 5).

The report gave PM Howard and federal government leaders after him the opportunity to permanently militarize the Northern Territory and reinforce an assimilative agenda upon the Indigenous population, who were radically divided by the policies and policing imposed As Melissa Hinkson writes,

... the NT intervention is aimed at nothing short of the production of a newly oriented, 'normalised' Aboriginal population, one whose concern with custom, kin and land will give way to the individualistic aspirations of private home ownership, career, and self-improvement. It is suggested that this is the only possible way forward for Aborigines (Hinkson 2007, p. 6).

Much in the vein of Carpentaria, The Swan Book assesses the politics of non-Indigenous landownership and land management critically, with the abuse of natural resources inevitably leading to catastrophic environmental outcomes. As it was written in the wake of Carpentaria and against the backdrop of the Northern Territory Invasion, The Swan Book directly comments on the disempowerment, devastation, and corruption that result from any kind of trade-off with non-Indigenous, mainstream society in the struggle for sovereignty. With the wry irony and uncanny foresight that mark her style, Wright emulates the military framework of the NT Emergency Response, strengthened by bipartisan support: 
This was the history of the swamp ever since the wave of conservative thinking began spreading like wildfire across the twenty-first century, when among the mix of political theories and arguments about how to preserve and care for the world's environment and people, the army was being used in this country to intervene and control the will, mind and soul of the aboriginal people. The military intervention was seen as such an overwhelming success in controlling the Aboriginal world it blinded awareness of the practical failures to make anyone's life better in the swamp. This 'closed ear' dictatorial practice was extended over the decades to suit all shades of grey-colored politics far-away in Canberra, and by tweaking it ever so little this way and that, the intervention of the Army never ended for the swamp people, and for other Aboriginal people like themselves who were sent to detention camps like the swamp to live in until the end of their lives. The internment excluded the swamp people from the United Nations' Universal Declaration of Human Rights, and the control proliferated until there was full traction over what these people believed and permeance over their ability to win back their souls and even to define what it meant to be human, without somebody else making the decision for them (Wright 2017, p. 7).

The Swan Book reflects, then, through the plight of Oblivia and her swans, the bleakness of the Intervention in its description of current military control of dysfunctional Indigenous life in Australia's Northern Territory, and adds the severe effects of climate change, racial policy, and neocolonialism on the Australian population at large in a mutually reinforcing, destructive bind:

When the world changed, people were different. Towns closed, cities were boarded up, communities abandoned, their governments collapsed. They seemed to have no qualms that were obvious to you and me about walking away from what they called a useless pile of rubbish, and never looking back. Mother Nature? Hah! Who knows how many hearts she could rip out? She never got tired of it. Who knows where on Earth you would find your heart again? People on the road called her the Mother Catastrophe of flood, fire, drought and blizzard. These were the four seasons she threw around the world whenever she liked. In every neck of the woods people walked in the imagination of doomsayers and talked the language of extinction (Wright 2017, p. 7).

It is on the swampy, contaminated Swan Lake that Oblivia has found shelter and protection with Bella Donna of the Champions, a marginal female character who lives in a derelict old ship's hulk amidst a crowd of rusty "phantom vessels" — detritus left by the military when these tribal lands serve as navy dumping grounds (Wright 2017, p. 55). Bella Donna is a nomadic gypsy woman expelled by persecution and dispossession from Old Europe who emulates the politics of dispersion and genocide applied to the Aborigines. She claims to have been saved by a white swan one day, as Oblivia is by her pack of black swans, indicating that rescue is possible for both black and white, even if black swans were long believed not to exist in Europe. She teaches Oblivia her "foreigner's Dreaming" to control the newly arrived black swans, expelled from their former habitat by insistent drought (Wright 2017, p. 16). It is also Bella Donna who recovers Oblivia from the hole in a eucalyptus tree where she has been hiding and sleeping/forgetting after her traumatic sexual abuse, "like that Rip van Winkle fella of the fairy tale time ${ }^{6 "}$ (Wright 2017, p. 7). Her story has been turned into local myth by the Aborigines and, reminiscent of Plains of Promise, links her trauma causally to man-made local and continental climate change after white settlement and imposition:

Some say there was an accident before the drought. A little girl was lost. She had fallen into the deep underground bowel of a giant eucalyptus tree. In a silent world, the girl slept for a very long time among the trees huge woven roots. Everyone had forgotten that she even existed [...] This happened during 
the massive sand storms that cursed the place after the arrival of the strangers from the sea (Wright 2017, pp. 7-8).

Against this fateful backdrop the novel pits the arrival to political power of the first Indigenous-Australian Prime Minister, Warren Finch, who is expected to save the country from ecological disaster and is claimed to embody a balanced Indigenous/non-Indigenous future. The Elders' wish for Warren's arranged marriage with Oblivia, once cherished but abandoned after her rape, joins the very local story of the newly-named, contaminated Swan Lake and its displaced inhabitants-reminiscent of Plains of Promise's lost mission mob and its nameless disappearing lake- to the national scene, as Warren, once elected and strengthened in his role of national leader, is unwilling to obey the local Elders' orders. In the translation of the local into the national and continental that The Swan Book reveals its greatest strength, showing the mutually nourishing Dreaming connections between the micro and macro levels of nature and human society — and the dystopian devastation caused when its checks and balances are disrupted.

Oblivia enjoys a special relationship with the Lake's black swans, which seek her company after being pushed north from the drought-ridden south. The Aborigines regard the black swans as alien to the swamp, as "there was no song for swans," but having reached beyond the end of their songline, the beautiful birds have become permanent exiles like Oblivia. They are an omen, a "paragon of anxious premonitions," implicated in damaging difference "rather than a miracle for saving the world" (Wright 2017, p. 14). Associated with the "strange and unfamiliar" (Wright 2017, p. 15) and yet bent on making the lake their home, they enhance the sensation of madness or being "Warraku", that is, projected onto Oblivia's outsider status (Wright 2017, p. 15). The black swans' forced migration functions as a metaphor for the dire effects of Indigenous dispersal, disempowerment, and death in the area but also denotes the devastating effects of the mainstream mismanagement of the land in general. An ambiguous symbol of un/belonging, the swans take the place of the dangerous black crows in Plains of Promise's disappearing lake, whose life-giving secret ultimately occupies its dramatic action.

The solution to the disruption of the Dreaming was once sought in the now discarded union of Warren and Oblivia, but as in Plains of Promise, the local Elders merely act out of a sense of protection toward the boy and girl once chosen to lead the country to survival and regeneration. Yet, the possibility of regenerating country, so intimately linked to the purity of the female body, seems now forever lost, with Oblivia cast into silence, forgetfulness, and madness. The far-reaching consequences of Oblivia's rape and the general sense of tribal fragmentation on and around the swamp renamed as Swan Lake are rewrites of the themes of gendered and racial violence that inform Plains of Promise. Ivy's madness and outcast status are the result of her abuse by Missioner Jipp as well as of the ${ }^{7}$ all of which leads to the dramatic crises in the novel centering on reestablishing the balance in country as it existed prior to contact with the white man. These crises are foreshadowed and embodied through the flooding and drying of the Disappearing Lake on tribal grounds, which are the harbingers of local Indigenous life and death. The overlap of race and gender oppression in Ivy's life is complicated in Oblivia's life, where the perpetrators of sexual violence are young males from her own mob, while her former fiancé is not the knight in shining armor promised but an intensely problematic alpha male.

Warren Finch's behavior recalls messenger Elliott Pugnose's rebellious attitude and political activist Buddy Doolan's destructive male chauvinism in Plains of Promise. In his search for Indigenous manifest destiny, Warren defies the Elders' designs by insisting on marrying Oblivia. Thus, he forces her to join him to the dire environment of the Garden City, where she is to lead a secluded life locked away in his apartment while he dedicates himself to the political game, only vaunting her in public when this is advantageous to his agenda. Yet, post-apocalyptic Canberra ultimately proves a deadly trap and Warren is assassinated by his political opponents shortly after the betrothal. It causes Oblivia to flee back to the Lake in the company of her flock of black swans to reestablish the nourishing links with country she had to forsake in coming to the dismal Garden City, 
where lost, poverty-stricken humans dwell and the few wealthy and powerful reside in gated seclusion. The City is a place of post-apocalyptic doom, "a foggy maze of concrete industrial buildings, high-rise offices, factories and houses," devoid of birds, cracking at the seams and full of beggars (Wright 2013, pp. 208-9), which spells utter distrust in the results of political action when played according to the corrupt rules of the democratic mainstream game.

Warren Finch parades as a power-hungry, masculinist Indigenous parvenu who musters up little sympathy as the 'savior' of Australia, be it Indigenous or non-Indigenous (Wright 2013, p. 185). At first glance, Finch appears as an empowered and more sophisticated rewrite of Buddy Doolan in Plains of Promise, but more disturbing links can be established with real-life politicians related to the NT Invasion in a composite of several contemporary Indigenous leaders of controversial reputation-not unlikely as Wright knows the impact of gender on activism from her own experience, which contributed to her decision to switch to writing as a means to serve her people. Notably, Warren may be inspired by his namesake Warren Mundine, the President of the Indigenous Advisory Council appointed by the late, conservative Abbott Government, associated as he is with moral corruption after his long involvement with Australian Labor as the party's National President and his subsequent defection to the Conservative party. Both Warrens seem to be continuously at war with their political surroundings, and not very reliable leaders.

Finch's characterization as an empowered, capitalist sell-out also recalls the Indigenous Cape-York activist Noel Pearson, whose singular, liberal opinions on Indigenous dysfunctionality and its remedies supported PM John Howard's intervention in the Northern Territory after the Little Children Are Sacred report was published. As Raimond Gaita writes, "It [the Intervention] probably could not have happened without Pearson: not the intervention itself, nor the broad consent to it" (Gaita 2007, p. 297). To many an observer, Howard's assimilationist, neocolonialist bid to save Indigenous children stands as a perverse scheme that blatantly cashes in on the Stolen Generations' plight in order to disenfranchise remote Indigenous communities. Jon Altman lists the regressive consequences of the emergency legislation, which range from curbing welfare, supervising community activities and projects, and imposing mandatory work on the unemployed to contracting professional managers in local government, and highlights how the federal government is fully aware that these measures of reform are "racially discriminatory" but defends them with the perverse, worn argument that they are "beneficial" within "the terms of the Racial Discrimination Act 1975 and the Constitution" (Altman 2007, p. 311).

Wright gives another, environmental clue to her view of Indigenous leaders going mainstream: the finch, Warren's family name, is a European songbird whose everydayness and small size contrast with the exceptionality and beauty of the native black swans. Also, Warren's first name may connote either a breeding pen for rabbits or the complex maze of burrows with which this imported European pest undermines the Australian habitat. In other words, it refers to a negative site of containment, delusion, and disorientation, which seems to connect with the sense of co-opting that the Indigenous leader conveys.

Through the black swans, Wright not only highlights the existence of an incommensurable Indigenous world on Australian soil but also illustrates the incongruence and inappropriateness of Warren Finch's arranged marriage with Oblivia, who is inseparably associated with the lake's black swans through the Dreaming; her strong natural connection and outcast status as a human are poised against Warren's materialistic, self-interested drives and convictions. Wright ultimately debunks the myth of powerful male Indigenous leadership ${ }^{8}$ in the description of Finch's funeral rites, a "Travelling Road Show" commercialized for the tourist industry and grounded in the iron laws of capitalist production and consumption through the use of a cooled long-haul delivery truck as his hearse (Wright 2013, p. 284). In the chapter entitled "The Ghost Walk", Warren's body is readied for a mocking "last lap of honour" (Wright 2013, p. 295), and the irony of Warren's sobriquet "The Spirit of the Nation" in his move from vital essence to ghostly presence will not be lost on the reader: 
The coffin was soon popped in the deep freezer of the Fresh Food People long-haul semitrailer attached to the Mack's cab-now painted up in blue, red and white, as though draped with the nation's flag [...] The See You Around journey was for all people who bothered to stand out in a chilly night, or in the midday sun, if they cared enough to line the streets just to watch the Spirit of the Nation roaring by [...] the clockwork nature of the thing was to keep the Fresh Food People's schedule of deliveries to its supermarket chain throughout the country (Wright 2013, pp. 294-297).

The closing chapters see Oblivia's safe return to the Swan Lake after a long, hazardous journey in the company of her swans. From this moment on, the scene almost necessarily shifts to the eternal movements of the natural cycle: wet and drought, life and death alternate as behoove and the story of the disappearing and reappearing swans is cast in a timeless, distancing Dreamtime perspective of constant renewal. This takes us back to Elliot Pugnose's waterbird Dreaming that closes, informs, and summarizes Plains of Promise. The Swan Book's epilogue equally terminates in a mythical tale that ties the end to the beginning and projects the cycle of life, based on the alternating absence and presence of water, that most feminine of the classic four elements:

Having lived in the dry country for several thousands of years, the ghostly spectre of the drought woman had seen as many generations born and die and when those beautiful swans rose up one day to the skies and disappeared, it broke the water lilies and weed-covered lagoon, pulled itself out of its resting place, and filled the atmosphere from coastline to coastline of rotted tree stumps, flat plains, or solemn river bends across the country. Then it continued in the southerly direction the birds had flown. In its far-flung search for the swans, the slow-moving drought left behind smouldering ashes and soil baked by the dryness, and the whole country looking as though it had been turned over with a pick and flattened with a shovel. When the swans were found, the drought turned around on its hot heels and howling winds, while fires blew smoke across the lands on fast moving currents, and came back to the swamp (Wright 2013, p. 330).

A sense of return to origins and resolution is achieved in Oblivia's address of the personified drought, which may hold the key to a better future and follows directly on the passage just quoted. She now commands the drought woman to take care of the last displaced fledgling swan that Oblivia is having under her wings and that she calls "Stranger", which denotes her recovery of initiative and a healing of sorts after long years of depression, oblivion, and sullenness: "I am done with carrying it around with me. You look after this swan, she ordered. His name is Stranger. Thinks he doesn't belong in drought country. See if you can make more swans of this, old pensioner" (Wright 2013, p. 330). All is not lost at the end of this dystopian novel, provided race, gender and nature are duly addressed.

\section{Conclusions: Swansong or Songline?}

No doubt Wright took the Northern Territory Emergency Response, also known as NT Intervention or NT Invasion, as the blueprint for her dystopian imagination of Indigenous Australia's future in The Swan Book, and much of its narrative signals back to the current situation of military control and oppression at the Top End. As an Indigenous dystopia, The Swan Book is pitched between the pessimism of the preceding Plains of Promise (1998) and the relative optimism of the awarded Carpentaria (2006), as it adapts and juggles the plot elements of its prequels to strike a sustainable balance in narrative form and content. The Swan Book revisits the themes of Wright's previous two novels and merges them into a new, epic tale of Indigenous hope and despair, swansong or songline, denouncing the injustice of mainstream imposition but also achieving enough distance to mock the euphemistic rhetoric of oppression engendered by what Rob Nixon coined "slow violence". No doubt many a description in the novel will draw wry smiles on the face of the reader. 
The Indian cultural studies scholar Ashis Nandy holds that minority "cultures are refusing to sing their swansongs and bow out of the world stage to enter the textbooks of history. Indeed, [such] cultures have now begun to return, like Freud's unconscious, to haunt the modern system of nation states" (Offord et al. 2014, p. 113). In Australia, Indigenous fiction plays an important part in this process and, as a major creative impulse, is enjoying increasing recognition. Alexis Wright is a main exponent of this turn of literary events that has developed from Indigenous life writing to telling stories 'truer than the truth' through fiction, which led to The Swan Book's being shortlisted for 2014's Miles Franklin Award. Written with the erudite irony and engagement that characterize her style, Wright's latest novel is not a dystopian swansong of death and resignation provoked by the assimilative impositions of mainstream society, notably the Northern Territory Invasion, but a critical songline into a possibly empowering future for Australia's Indigenous communities-a native/Indigenous black swan of sorts. Wright employs the power of imaginative fiction to shed the shackles that trap the Indigenous mind. As the authorial voice announces in The Swan Book's prelude, in order to free herself from the contagion of the settler's way, she has created fiction as a mental Native Title in "the quest to regain sovereignty over my own brain" (Wright 2013, p. 4), as well as, one should add, over her Indigenous body and traditional country.

Funding: This research received no external funding.

Institutional Review Board Statement: Not applicable.

Informed Consent Statement: Not applicable.

Conflicts of Interest: The author declares no conflict of interest.

\section{Notes}

1 The Fourth World refers to those populations that live in Western societies but in Third World conditions.

2 The "smoothing of the dying pillow" was a colonial metaphor that reflected the unquestionable demise of the Aboriginal race due to the strength and superiority of white civilization: the common understanding was that the Indigenous peoples should be helped and eased onto their path towards extinction. It tied in with the policy of the Stolen Generations, for example, which nowadays is commonly seen as a form of slow genocide. Alexis Wright uses the term ironically in The Swanbook (p. 49).

3 Terra Nullius is Latin for "land belonging to nobody" and denotes the legal doctrine that forfeited the Indigenes' right to their land on the basis of their not being human, which upholds the white presence in current Australia.

4 In the national newspaper The Age, Jenny Pausacker reviewed the novel as an exponent of "an authentically Australian magical realism that puts imported versions into new perspective" (see the novel's back blurb of the UQP edition (1997)), but it is debatable whether magic realism is the label that would fit this novel best. I proposed "Uncanny Realism" but now also opt for "Aboriginal Reality" after Wright's own suggestion. As was pointed out by the Indigenous scholar, poet, and writer Jeanine Leane at the 2013 ASAL congress at Sturt University, NSW, Alexis Wright has casually spoken of "Aboriginal Reality" as a generic term for recent Indigenous Australian fiction that fits deconstructive purposes. The term evidently plays on Magical Realism, which risks assimilating a discrete world of the magical or marvelous to realism, fantasy to reality, the Ideal to the Real, and the Other to the Self from the perspective of Western Reason, while it also reacts to Mudrooroo's coinage of Maban Reality.

5 Deborah Bird Rose describes the dreaming as a series of origin stories that explain how in a distant past the Totemic Ancestors gave shape to the elements, the land, and all life forms, organizing all into an interconnected and interdependent network. Totemic spirits are contained in the physical features of the land and denote the ongoing connection of the Dreamtime with contemporary Aboriginal societies. Dreamtime sites have Secret-Sacred qualities and, within clan law and logic, are not to be visited without due preparation and authorisation. Indigenous possession of the land is interpreted as custodianship; this is the care for and the observance of ritual related to the land and all that lives on it, especially where sacred sites are concerned.

6 The Rip Van Winkle tale, a short story written by the American author Washington Irving in 1819, tells how Rip, a somewhat lazy farmer of Dutch ancestry, sleeps for twenty years after drinking moonshine with what seems to be a group of Dutch first settlers in the hills around his village in the Catskills. When he wakes up and returns home, his fellow townspeople no longer recognize him, and it takes some time for him to realize that he has actually slept through the American Revolution, which provokes the villagers' jealousy, as they would have liked to do without the Revolution's hardships. The irony here is that Oblivia, unlike Rip, falls asleep precisely to forget her traumatic hardships.

7 Black Velvet stood for the sexual engagement of white frontiermen with Aboriginal women. As these men often did not take responsibility for their mixed-descent offspring, this practice fed into the Stolen Generations policy in the 20th century, which 
separated these children from their Aboriginal caretakers and fostered them out or put them in care of institutions with the objective of assimilating them in white society as a menial labour force.

8 Note that Alexis Wright's latest publication, Tracker is the biography of, and homage to, an enabling and empowering Indigenous male leader, the activist Tracker Tilmouth, recently deceased.

\section{References}

Altman, John. 2007. In the Name of the Market? In Coercive Reconciliation: Stabilise, Normalise, Exit Aboriginal Australia. Edited by John Altman and Melinda Hinkson. Melbourne: Arena, pp. 307-24.

Attwood, Bain. 2005. Telling the Truth about Aboriginal History. Crows Nest: Allen \& Unwin.

Behrendt, Larissa. 2001. Genocide: The Distance Between Law and Life. Aboriginal History 25: 132-47. [CrossRef]

Bird Rose, Deborah. 2000. The power of place. In The Oxford Companion to Aboriginal Art and Culture. Edited by Sylvia Kleinert and Margo Neale. Oxford: Oxford UP, pp. 40-49.

Gaita, Raimond. 2007. The Moral Force of Reconciliation. In Coercive Reconciliation: Stabilise, Normalise, Exit Aboriginal Australia. Edited by Jon Altman and Melinda Hinkson. North Carlton: Arena, pp. 295-306.

Gelder, Kenneth, and Jane Jacobs. 1998. Uncanny Australia: Sacredness and Identity in a Postcolonial Nation. Melbourne: Melbourne UP.

Grossman, Michèle. 1998. Reach On Out to the Other Side: Grog War and Plains of Promise. Meridian 17: 81-87.

Grossman, Michele. 2006. Risk, Roguery and Revelation. Available online: http:/ /infoweb.newsbank.com/iw-search/we/InfoWeb?p_ product=AWNB\&p_theme=aggregated5\&p_action=doc\&p_docid=1148A0D9851BE068\&p_docnum=1\&p_queryname=16 (accessed on 9 September 2008).

Hinkson, Melinda. 2007. Introduction: In the Name of the Child. In Coercive Reconciliation: Stabilise, Normalise, Exit Aboriginal Australia. Edited by Jon Altman and Melinda Hinkson. Victoria: Arena, pp. 1-12.

Kunhikrishnan, K. 2003a. Identity Narratives. The Hindu. Available online: http://www.thehindu.com/thehindu/lr/2003/04/06 / stories/2003040600180300.htm (accessed on 3 May 2008).

Kunhikrishnan, K. 2003b. Reclaiming a Heritage. The Hindu. Available online: http:/ /www.thehindu.com/the-hindu/lr/2003/04/06 / stories/2003040600180300.htm (accessed on 3 May 2008).

Manne, Robert, ed. 2003. Whitewash: On Keith Windschuttle's Fabrication of Aboriginal History. Melbourne: Black Inc. Agenda.

Moses, Dirk A., ed. 2005. Genocide and Settler Society: Frontier Violence and Stolen Indigenous Children in Australian History. New York and Oxford: Berghahn.

Nixon, Rob. 2011. Slow Violence and the Environmentalism of the Poor. Cambridge and London: Harvard University Press.

OED. 2021. "dystopia". Oxford English and Spanish Dictionary, Synonyms, and Spanish to English Translator. Available online: https: //www.lexico.com/definition/dystopia (accessed on 14 November 2020).

Offord, Baden, Erika Kerruish, Rob Garbutt, Adele Wessell, and Kirsten Pavlovic. 2014. Inside Australian Culture: Legacies of Enlightenment Values. Foreword by Ashis Nandy, afterword by Vinay Lay. London and New York: Anthem.

Perlez, Jane. 2007. Aboriginal Lit. New York Times, November 18.

Ravenscroft, Alison. 2012. The Postcolonial Eye: White Australian Desire and the Visual Field of Race. Farnham and Burlington: Ashgate.

Renes, Cornelis Martin. 2002. Discomforting Readings: Uncanny Perceptions of Self in Alexis Wright's Plains of Promise and David Malouf's Remembering Babylon. Eucalypt 2: 76-102.

Reynolds, Henry. 2003. The Law of the Land. Ringwood: Penguin Australia.

UQP edition. 1997. Quoted on the back cover of Plains of Promise.

Wild, Rex, Julie Nicholson, and Patricia Anderson. 2007. Ampe Akelyernemane Meke Mekarle: "Little Children Are Sacred": Report of the Northern Territory Board of Inquiry into the Protection of Aboriginal Children from Sexual Abuse. Darwin: Northern Territory Government. Available online: https://humanrights.gov.au/sites/default/files/57.4\%20\%E2\%80\%9CLittle\%20Children \%20 are\%20Sacred\%E2\%80\%9D\%20report.pdf (accessed on 10 July 2015).

Windschuttle, Keith. 2002. The Fabrication of Aboriginal History, Vol. 1: Van Diemen's Land 1803-1847. Sydney: Macleay.

Wright, Alexis. 2002. Politics of Writing. Southerly 62: 10-20.

Wright, Alexis. 2013. The Swan Book. Artarmon: Giramondo.

Wright, Alexis. 2017. Tracker. Artarmon: Giramondo. 